\title{
Development of Metalanguage Competence through Content and Branch Training
}

\author{
Madeniyet Akhmetova', Salima S. Kunanbayeva² \& Markhabat \\ Kassymbekova ${ }^{3}$ \\ ${ }^{1}$ PhD Student, Kazakh Ablai khan University of International Relations and World Languages, \\ Almaty, Kazakhstan \\ ${ }^{2}$ Doctor of Philological Sciences, Professor, Academician, Kazakh Ablai khan University of \\ International Relations and World Languages, Almaty, Kazakhstan \\ ${ }^{3}$ Kazakh Ablai khan University of International Relations and World Languages, Almaty, \\ Kazakhstan
}

First published September 30, 2019

\begin{abstract}
:
This article considers methods for developing metalanguage competence through content and branch training. Metalanguage competence is among the most important professional competences for the specialist's formation in the sphere of foreign-language education within the framework of content and branch training. Metalanguage competence implies the accumulation of terminological knowledge and the ability to properly use foreign terms. For content and branch training, it is very important to have metalanguage competence since any sphere and field are characterized by their own specific terminology, which can be understood in a foreign language by learning the metalanguage of an industry through primary consciousness constructs in one's native language. As a result, one can operate a specialized terminology in a foreign language. In the framework of foreign-language education, specialists in natural sciences should master a specific terminology for intercultural communication at a professional level since terms reflect main provisions in any field of knowledge and contain basic professional information. This article describes the experiment and its results achieved in the work with students at the Kazakh Ablai Khan University of International Relations and World Languages in order to determine the current development of metalanguage competence in content and branch training.
\end{abstract}

Keywords: metalanguage competence, content and branch training, foreign-language education, terminological knowledge, content-oriented education.

\section{Introduction}

Nowadays, professionals are highly demanded in any field of knowledge. Throughout the development of economic and political relations between countries, the accession of the Republic of Kazakhstan to the Bologna process and its inclusion into the international educational space, dramatic changes are taking place in the education system. Due to these processes and the globalization of modern education, requirements for graduates of higher education institutions are increasing. Therefore, Kazakhstan needs highly qualified competitive personnel capable of professional communication in a multicultural environment. A modern specialist should be competent and possess professional competences that can be used in practice. To be in demand in the international labor market, it is necessary to be a competent specialist and speak English at a professional level. Today it is not enough to speak a foreign language, it is also important to be

(c) AesthetixMS 2019. This Open Access article is published under a Creative Commons Attribution Non-Commercial 4.0 International License (http://creativecommons.org/licenses/by-nc/4.o/), which permits non-commercial re-use, distribution, and reproduction in any medium, provided the original work is properly cited. For citation use the DOI. For commercial re-use, please contact editor@rupkatha.com. 
proficient in it and be able to establish professional contacts with representatives of different cultures in a certain area of knowledge.

In modern Kazakhstan, special attention is paid to the study of English. English is the language of international communication, science and technology. A person speaking English can discover a whole new world, consider the future from a different perspective and enjoy great prospects. To master English at a professional level and to teach it as an academic discipline, the appropriate pedagogical staff is necessary since a foreign language teacher should be highly qualified.

Modern education in the Republic of Kazakhstan aims to teach some natural science disciplines in English. Due to the lack of specialists capable of teaching these disciplines in English, the Republic of Kazakhstan has developed and is currently implementing the state program entitled "Roadmap for the development of trilingual education for 2015-2020" that intends teaching some natural science disciplines in English [Roadmap for the development of trilingual education for 2015-2020 as of November 13, 2015 No. 1066].

To this end, it is necessary to prepare specialists capable of teaching natural science disciplines in English. One of the possible options for solving this problem is the preparation of English teachers for natural sciences. Regarding their inclinations, students will be able to independently choose their future specialization.

Based on the methodology of foreign-language education, we consider the competencebased approach as one of the most relevant and productive approaches in the educational process. Its introduction into the system of higher vocational education significantly increases the competitive abilities of graduates in the international labor market. Moreover, collaboration with employers is more successful since graduates (future specialists) do not only accumulate the knowledge gained at the university, but also implement it at their workplace.

According to S. Kunanbayeva (2016), "the nature of competence is such that it is not just a product of learning, but is rather a consequence of self-development, self-organization and personal experience of an individual. Therefore, competence emerges as a complex synthesis of cognitive, subject-practical and personal experience, it cannot be formed by giving the learner a task, it must pass through a series of situations close to reality that claim him/her more competent actions, assessments and reflection" (Kunanbayeva 2016, p. 7265). Within the framework of content and branch training, metalanguage competence is among the most important professional competences for the specialist's formation in the sphere of foreignlanguage education. Metalanguage competence implies the accumulation of terminological knowledge and the ability to properly use foreign terms.

The term "metalanguage" (derived from the Greek "meta" - through, after - the language of the "second order").

Psychologists compare metalanguage abilities with conscious speech activities, while linguists interpret this ability as the metalinguistic function of any given language. According to R. Jakobson [Jakobson, 1975], the metalinguistic function of any language is intended to present itself and explain speech. The metalinguistic function is also used in difficult situations during communication. For content and branch training, it is very important to have metalanguage competence since any sphere and field is characterized by their own specific terminology which can be understood in a foreign language by learning the metalanguage of an industry through primary consciousness constructs in one's native language. As a result, one can operate a specialized terminology in a foreign language. Therefore, metalanguage competence is regarded 
as the ability to use a language in the metalinguistic function and convey one's message by linguistic means. The explanation of one's ideas implies the understanding that the same idea can be conveyed by different words due to a certain communicative situation. To work with scientific provisions and terms in a certain area of knowledge, it is necessary to know the subject or content of the chosen discipline. Natural science specialists in the sphere of foreign-language education should know specific terms necessary for intercultural communication at a professional level since terms reflect main provisions in any field of knowledge and contain basic professional information. In addition, concepts are reflected in terms that form knowledge and skills.

\section{Literature Review}

In recent years, the education system of the Republic of Kazakhstan has undergone significant changes: the government adopted a new long-term State Program for the Development of Education for 2011-2020 and approved a new edition of the Law of the Republic of Kazakhstan "On Education". In three years, Kazakh schools plan to teach some disciplines in English. Today there are few content-oriented programs in high school that use English as a means of studying mathematics, chemistry, biology and other academic disciplines. Modern schools have the right to choose from one to four disciplines that would be taught in English. For instance, natural science disciplines are physics, chemistry, biology and computer science. The metalanguage of natural science disciplines can be difficult for students. Content-oriented education is challenging because metalinguistic vocabulary is specific and complex, i.e. it contains specific terms.

The interpretation of metalanguage competence in psycholinguistics is associated with the metalinguistic function. Reflection as a component of metalanguage competence relates to deliberate communicative intentions and a conscious choice of linguistic means. Roman Jakobson's model of communicative functions regards the "metalinguistic" or "reflexive" function as one of the main functions of any given language (referential, emotional, conative, fatal, metalinguistic and poetic) [Roman Jakobson]. The metalinguistic function of any language "requires the analysis of such a language and its use to discuss the above-mentioned language" [Tribus, Angela]. While analyzing R. Jakobson's model, Tribus (2017) wrote that "the metalinguistic function is associated with statements dealing with the language itself (of a linguistic nature) or the so-called "code". It can be used to describe semantic and grammatical structures, provide students with tools to control their own learning process and clarify misunderstandings" (Tribus, 2017, p. 19).

The term "metalinguistics", originated in the 1950s, is used to denote the field of research related to "metalanguage", i.e. the language people use when referring to the language itself based on a linguistic terminology (for example, syntax, morpheme, object, verb or article) [Tsang Wai Lan]. According to McArthur, metalanguage is the "language used to speak about the language itself" [1992, p. 652].

S.S. Kunanbayeva also allocates information-accumulating metalanguage sub-competence. The researcher notes that this sub-competence aims "to gather information in the field of political, legal, social and economic sciences; to rethink and express it in small foreign discourses" (Kunanbayeva, 2015, p. 119), i.e. the scientist focuses on the accumulation of information through metalanguage.

Linguistic studies demonstrate that the desire for mastering a foreign language has dramatically changed in recent years. The level of language proficiency was assessed as the student's knowledge of language structures, but little attention was paid to the use of these 
language structures. When the concept of communicative competence was introduced into the field of foreign languages, the focus shifted from a narrow view of language proficiency to a wider range of language possibilities, including the understanding of language syntax, terminology, phonology and semantics (metalinguistic awareness) (Somaye Nazarian \& Siros Izadpanah).

Content and branch training also includes object competence comprising the metalinguistic component. The metalinguistic component is the most important element of the professional competence of a foreign language specialist and assumes the accumulation of terminological knowledge and the ability to properly use foreign terms. The information unit of a specialized text is a term regarded as a lexical unit.

Content-oriented education is not just the study of linguistic terminology; it also has other objectives. To develop metalanguage competence, students need opportunities for interaction in meaningful contexts and learning a foreign language in different situations. According to Krashen's theory, students "master languages in only one way when they understand messages, i.e. receive an "understandable contribution". Therefore, it is necessary to develop lessons that make metalanguage understandable. Metalanguage becomes more understandable when it is embedded in some context or is specific to such content, "where language is filled with both visual and oral cues" [Schleppegrell, 2013].

There are different models of metalanguage competence. Metalanguage competence consists of the following elements:

- Pragmatic component;

- Reflection of language;

- Evaluation of individual style and language skills.

Moscowskaya and Pirverdieva define metalanguage competence as a multicomponent phenomenon involving the knowledge of a certain linguistic system and specific terms (cognitive component), the ability to fulfill professional speech actions through a foreign language, the participation in professional communication (pragmatic component), the readiness to observe one's speech and conduct its analysis (reflexive component), as well as the ability to use adequate language means depending on a particular educational situation (didactic and adaptive component) [Moscowskaya \& Pirverdieva, 2011].

S. Halverson presents metalinguistic knowledge as "a strategic competence", the ability to reflect and manipulate language, an analytical attitude to language (Halverson, S., 2018, p. 16).

According to L. Sun, metalinguistic awareness refers to linguistic knowledge, deliberate language structures and their functions (Sun, L., 2016).

According to S. Candry, and other scholars, the most important factor determining the student's ability to identify the conformity between a form and meaning is the degree of metalinguistic awareness. These researchers tried to determine whether the student's level of metalinguistic awareness influences their ability to find a correspondence among a form, meaning and word (Candry, S., Deconinck, J., \& Eyckmans, J. (2017).

The development of the student's metalanguage competence contributes to self-control, evaluation of speech and successful communication. Metalanguage competence is an essential element of professional communicative competence and includes the accumulation of terminological knowledge and the ability to properly use linguistic terms, i.e. to define them 
correctly, to include them in terminological paradigms, to relate to linguistic facts and enter the existing scientific discourse.

\section{Methods}

\section{Research design}

To determine the development of metalanguage competence through content and branch training, we were conducting an experiment for ten months. Twenty-five attendees of preuniversity courses at the Kazakh Ablai Khan University of International Relations and World Languages (12 in the experimental group, 13 in the control group) took part in the experiment.

\section{Sample and instrumentation}

The experiment participants were two groups of attendees of pre-university courses at the Kazakh Ablai Khan University of International Relations and World Languages studying from September 2017 to July 2018 in conformity with the state program for further admission to Kazakh universities and acquisition of a pedagogical specialty for teaching natural science disciplines in English selected on the basis of a placement test. This test consisted of 50 questions compiled by teachers of the department of the second higher education of the Kazakh Ablai Khan University of International Relations and World Languages, including those concerning vocabulary and grammar of the English language, and was aimed to determine the level of their language training. The collection of the study-related data was based on the proposed texts and corresponding exercises, as well as tests from the textbook "Big Science 3 Student Book" (2016) and video materials from YouTube. For ten months, the experimental group used the textbook "Big Science 3 Student Book" (2016) in addition to "New English File, Pre-Intermediate, Student's Book" (2005), as well as videos from YouTube with educational materials on the topics of lessons. All these materials contained natural science content, terminology and metalanguage on natural sciences in English, which contributed to the development of the metalanguage competence of these students.

\section{Data analysis}

At the end of the experimental period, both groups were compared to determine whether their development of metalanguage competence differed. To this end, the participants were given a test comprising reading and listening tasks based on natural science texts. The Reading section consisted of two short texts, ten true/false tasks and ten multiple choice tasks. The Listening section consisted of one short text and eight "fill in the gaps" tasks. The test results were processed using methods of statistical calculation and mathematical prediction to determine the level of metalanguage.

\section{Validity and reliability}

Organizational and preparatory work included the following activities:

1) Purposeful observation of the learning process in the control and experimental groups;

2) The analysis of the students' performance;

3) The choice of the experimental and control groups; 
4) The selection of video and audio materials on a specific natural science topic with due regard to their specialized focus, authenticity, communicative expediency and variability of statements;

5) The development and systematization of communication tasks and exercises for working in the classroom.

To determine the development of metalanguage competence in content and branch training and ensure the reliability and scientific validity of the experiment results, we identified the following functions of the control and experimental groups:

- The control group learnt using only "New English File Pre-Intermediate Student's Book" (2005) in the framework of the traditional methodology without the use of metalanguage;

- The experimental group learnt using "New English File Pre-Intermediate Student's Book" (2005) in the framework of traditional methods. They additionally read and worked with authentic natural science texts filled with specific metalanguage, watched videos and listened to audio materials on YouTube, did exercises using branch-related active vocabulary.

- The control and experimental groups participated in pre- and post-experimental activities to check the development of their metalanguage competence in content and branch training.

\section{Results}

The control and experimental groups were formed according to the results of the Placement Test measuring the level of their English proficiency. To determine the desired level of proficiency in the English language, students were given a standard level test (Table 1).

Table 1. The desired level of foreign-language knowledge in the experimental and control groups.

\begin{tabular}{|l|l|l|}
\hline Groups & Number of participants & $\begin{array}{l}\text { Average credits in the English } \\
\text { language }\end{array}$ \\
\hline Experimental group (101) & 12 & 86.6 \\
\hline Control group (102) & 13 & 88.2 \\
\hline
\end{tabular}

The data in Table 1 reveals the academic performance of the experimental and control groups in the English language. The average score in the control group was slightly higher than in the experimental group, which indicates the reliability of the experimental data.

Invariable conditions (same experiment duration for both groups) comprised the same educational material, the same number of foreign language lessons and the same forms of control.

Variable components of the experiment included the use of authentic natural science texts filled with a metalanguage, as well as corresponding video and audio materials on YouTube. The control group was taught without the use of natural science texts, video and audio materials.

Before conducting the experiment, we should determine English language skills in these groups. To this end, we carried out a pre-experimental work in both groups and used the method of testing. The Placement Test compiled by teachers of the department of the second higher education consisted of fifty questions, including lexical tests and grammatical tasks based on the 
knowledge of tenses, use of prepositions, conditional sentences, pronouns, articles, modal verbs, degrees of comparison of adjectives and adverbs.

Using the methods of statistical calculation and mathematical prediction, we determined the level of English proficiency (\%) with the following formula:

$$
x=\frac{R a}{\mathrm{Sn}}
$$

Where $X$ is the level of English proficiency (\%); Ra is the number of the right answers; $\mathrm{Sn}$ is the number of participants multiplied by the number of tasks. Students' works were analyzed and compared. The results of the pre-experimental diagnosis are presented in the table below (Table 2):

Table 2. The experiment results.

\begin{tabular}{|c|c|c|c|c|c|c|}
\hline \multirow[b]{3}{*}{ Leve } & \multicolumn{2}{|c|}{ Number of participants } & \multicolumn{2}{|c|}{$\begin{array}{l}\text { Sum of received } \\
\text { credits }\end{array}$} & \multicolumn{2}{|c|}{ Result, \% } \\
\hline & $\begin{array}{l}\text { Experiment } \\
\text { al group } \\
12 \text { students }\end{array}$ & $\begin{array}{l}\text { Control } \\
\text { group } \\
13 \text { students }\end{array}$ & $\begin{array}{l}\text { Experiment } \\
\text { al group }\end{array}$ & $\begin{array}{l}\text { Control } \\
\text { group }\end{array}$ & $\begin{array}{l}\text { Experi } \\
\text { menta } \\
1 \\
\text { group }\end{array}$ & $\begin{array}{l}\text { Contr } \\
\text { ol } \\
\text { group }\end{array}$ \\
\hline & & & & & & \\
\hline $\begin{array}{l}\text { Optimal level } \\
\text { (excellent) }\end{array}$ & - & - & - & - & o\% & o\% \\
\hline $\begin{array}{l}\text { High level } \\
\text { (good) }\end{array}$ & 3 & 4 & 20 & 41 & $33.3 \%$ & $55 \cdot 5 \%$ \\
\hline $\begin{array}{l}\text { Average level } \\
\text { (satisfactory) }\end{array}$ & 9 & 10 & 9 & 12 & $55 \cdot 5 \%$ & $44.5 \%$ \\
\hline $\begin{array}{l}\text { Low level } \\
\text { (unsatisfactory) }\end{array}$ & 3 & 1 & 2 & - & $11.2 \%$ & o\% \\
\hline Total & 15 & 15 & 31 & 53 & $100 \%$ & $100 \%$ \\
\hline Average indicator & \multicolumn{3}{|c|}{ Experimental group $=3.44 \%$} & \multicolumn{3}{|c|}{ Control group $=5.8 \%$} \\
\hline
\end{tabular}

As the pre-experimental study has shown, the control and experimental groups also had difficulties understanding the source text, which indicates the lack of foreign language proficiency. Students had little knowledge of specialized vocabulary since they demonstrated poor results while doing the "fill in the gap" tasks and used few topic words. 
Students in the experimental group used "Big Science 3 Student Book" (2016) in addition to their main English textbook. Teachers also compiled the vocabulary of chemistry terms that was used by the students throughout the entire educational course.

The process of experimental training considered the so-called variable and non-variable components. Variable components (depending on certain conditions) comprised educational materials, authentic texts, audio and video materials, metalinguistic exercises and natural science terms. This training was implemented in the experimental group. Non-variable components in the experimental and control groups included such unchangeable data as the number of hours, the same conditions for learning a foreign language, the same number of students in groups, the same teacher.

The educational material compiled for the experimental group contained a set of exercises for the formation of procedural aspects of communication in various types of speech activity; mastering the substantive content of communication; familiarizing with metalinguistic materials; as well as creative situational, variable situational, typical situational, polemic-argumentative, analytic-evaluative and regulatory-communicative tasks.

The content and branch complex under consideration was realized through the assimilation of metalanguage by means of differentiated communicative spheres corresponding to sub-topics and communicative situations.

At the end of the experiment, we conducted the post-experimental diagnosis of the formation of metalanguage competence in the experimental and control groups. The tasks for the post-experimental section were similar to those used for the pre-experimental diagnosis, but their content was different.

The results of the post-experimental section are demonstrated in the table below (Table 3).

Table 3. The post-experiment results.

\begin{tabular}{|c|c|c|c|c|c|c|}
\hline \multirow{3}{*}{ Results } & \multicolumn{2}{|c|}{ Number of participants } & \multicolumn{2}{|c|}{$\begin{array}{l}\text { Sum of received } \\
\text { credits }\end{array}$} & \multicolumn{2}{|c|}{ Result, \% } \\
\hline & $\begin{array}{l}\text { Experiment } \\
\text { al group } \\
12 \text { students }\end{array}$ & $\begin{array}{l}\text { Control } \\
\text { group } \\
13 \text { students }\end{array}$ & $\begin{array}{l}\text { Experim } \\
\text { ental } \\
\text { group }\end{array}$ & $\begin{array}{l}\text { Control } \\
\text { group }\end{array}$ & $\begin{array}{l}\text { Exper } \\
\text { iment } \\
\text { al } \\
\text { group }\end{array}$ & $\begin{array}{l}\text { Contr } \\
\text { ol } \\
\text { group }\end{array}$ \\
\hline & & & & & & \\
\hline $\begin{array}{l}\text { Optimal level } \\
\text { (excellent) }\end{array}$ & 4 & 1 & 40 & 12 & $33.3 \%$ & $11.1 \%$ \\
\hline $\begin{array}{l}\text { High level } \\
\text { (good) }\end{array}$ & 6 & 4 & 32 & 27 & $44.4 \%$ & $44.4 \%$ \\
\hline Average level & 2 & 8 & 9 & 19 & $22.2 \%$ & $44.4 \%$ \\
\hline
\end{tabular}




\begin{tabular}{|l|l|l|l|l|l|l|}
\hline (satisfactory) & & & & & & \\
\hline $\begin{array}{l}\text { Low level } \\
\text { (unsatisfactory) }\end{array}$ & - & - & - & - & $0 \%$ & $0 \%$ \\
\hline Total & 12 & 13 & 81 & 58 & $100 \%$ & $100 \%$ \\
\hline Average indicator & \multicolumn{2}{|l|}{ Experimental group $=9 \%$} & \multicolumn{2}{l|}{ Control group $=6.4 \%$} \\
\hline
\end{tabular}

The average indicator of the pre-experimental section conducted in the experimental group was 3.4\%, which is almost 2.5 times lower than the post-experimental indicator. The average indicator of the pre-experimental section conducted in the control group was $5.8 \%$, which is slightly lower than the post-experimental indicator.

Thus, the table above shows that the dynamic formation of metalanguage competence in the experimental and control groups differed. Students of the experimental group improved all the tested parameters, while the control group did not demonstrate significant growth of the same parameters.

While analyzing the post-experimental section, we can note that the control group preserved the same level of lexical proficiency on a given topic, and the experimental group extended their vocabulary, began to use metalanguage and terminology in natural science training due to additional content that is provided alongside the main textbook.

Therefore, we can conclude that content and branch training contributes to the formation and development of metalanguage competence, helps to study and speak foreign languages in certain areas of knowledge, encourages students to learn foreign languages, ensures the growth of knowledge in a particular sphere.

After analyzing the results obtained in the control and experimental groups, we sum up that the development of metalanguage competence through content and branch training has a greater didactic effect if compared to traditional methods.

The experimental work based on content and branch training has proved the development of metalanguage competence. All indicators show positive dynamics.

\section{Conclusion}

In this article, we aimed to show how content and branch training contributes to the development of metalanguage competence. Content and branch training is the main condition for the development of metalanguage competence. Metalanguage competence implies the accumulation of terminological knowledge on a certain subject and its appropriate use in speech activity, i.e. metalanguage is developed, and a terminological paradigm is used efficiently. The knowledge of a subject-related metalanguage lets students use language facts through the content provided in specialized texts and develop a scientific discourse in some sphere of knowledge. Metalanguage competence is realized both in oral and written communication, as well as in future professional communication. While mastering some subject-related metalanguage, students interpret the language itself, streamline and organize their linguistic experience, thereby form linguistic and metalinguistic knowledge. 
The experiment we conducted aimed to determine how metalanguage competence develops through content and branch training. The participants of this experiment used metalanguage as a regulatory tool for mediating and improving their mental processes, as well as promoting the English language. They used metalanguage for the common understanding of English.

The experiment has demonstrated that the students used metalanguage to study structural and semantic relations of the English language. Metalanguage became a means of overcoming language difficulties while reading authentic scientific texts in the sphere under study.

\section{References}

Baryshnikov, N.V. Osnovy professionalnoi mezhkulturnoi kommunikatsii: uchebnik [Foundations of professional intercultural communication]. Moscow: Vuzovskii uchebnik: INFRA-M, 2013. 368 pp.

Candry, S., Deconinck, J., \& Eyckmans, J. Metalinguistic awareness in L2 vocabulary acquisition: which factors influence learners' motivations of form-meaning connections? LANGUAGE AWARENESS, 26(3), 2017. P. 226-243.

Clive Oxenden, Christina Latham-Koenig, Paul Seligson. New English File Pre-intermediate Student's book, Oxford, University Press, 2005, 160 pp.

Dorozhnaya karta razvitiya trekhyazychnogo obrazovaniya na 2015-2020 gody ot 13 noyabrya 2015 goda No. 1066 [Roadmap for the development of trilingual education for 2015-2020 as of November 13, 2015 No. 1066].

Garet, M., Porter, A., Desimone, L., Birman, B., \& Yoon, K.S. What makes professional development effective? Results from a national sample of teachers. American Education Research Journal, 201, 38(4). P. 915-945.

Haliza Harun, Norhana Abdullah, NurSyuhada' Ab. Wahab \& Nurkhamimi Zainuddin. The use of metalanguage among second language learners to mediate L2 grammar learning. Malaysian Journal of Learning and Instruction (MJLI), 2017, 14(2). P. 85-114.

Halverson, S. Metalinguistic Knowledge/Awareness/Ability in Cognitive Translation Studies: Some Questions. HERMES - Journal of Language and Communication in Business, 57, 2018. P. 11-28. URL: https://doi.org/10.7146/hjlcb.voi57.106191

Herrera Mario, Big Science 3 Student Book, Pearson Education, Longman, 2016, 176 pp.

Jakobson, R. On Language. Cambridge: Harvard University Press, 1995.

Jakobson, R.O. Lingvistika i poetika [Linguistics and poetics] // Strukturalizm: "za" i "protiv". Moscow, 1975. P. 197-203.

Kunanbayeva, S., Zhyltyrova, Z. The Development of Professional Foreign Language Competence for ESP Students: Case of Kazakh National Agrarian University Students, INTERNATIONAL JOURNAL OF ENVIRONMENTAL \& SCIENCE EDUCATION 2016, VOL. 11, NO.14, P. 7262-7270.

Kunanbayeva, S.S. Strategicheskie orientiry vysshego inoyazychnogo obrazovaniya [Strategic guidelines of higher foreign-language education]. Almaty, 2015. 119 pp.

Mary J. Schleppegrell. The Role of Metalanguage in Supporting Academic Language Development, Language Learning 63, University of Michigan: Suppl. 1, March 2013, P. 153-170. 
Moskowskaya, N.L., \& Pirverdieva, Yu.A. Metalingvisticheskaya kompetentsiya lingvista-prepodavatelya: genezis i soderzhanie [The metalanguage competence of a linguist-teacher: genesis and content]. Nauka. Innovatsii. Tekhnologii, 2011, 73. P. 96-102.

Somaye Nazarian \& Siros Izadpanah. The Study of the Metalinguistic Knowledge of English by Students in an Intensive and a Traditional Course, International Journal of English Linguistics; Vol. 7, No. 1; 2017.

Sun, L. Analyzing bilingual advantage in metalinguistic awareness: the roles of executive functioning and vocabulary knowledge on metalinguistic tasks. UCLA, 2016. ProQuest ID: Sun_ucla_o031N_14669. Merritt ID: ark:/13030/m5qz6zkı. URL: https://escholarship.org/uc/item/5wn18640

Tribus, Angela C. The Communicative Functions of Language: An Exploration of Roman Jakobson's Theory in TESOL. MATESOL Collection, 2017. No. 723. URL: https://digitalcollections.sit.edu/ipp_collection/723

Tsang Wai Lan. English Metalanguage Awareness Among Primary School Teachers in Hong Kong. GEMA Online TM Journal of Language Studies 1, Volume 11(1), 2011. ISSN: 1675-8021. 